\title{
THE DISTRIBUTION \\ OF ELATINE HEXANDRA (LAPIERRE) DC. (ELATINACEAE)
}

\author{
AgnieszKa Popiela ${ }^{1}$, ANDRZej Łysko ${ }^{2}$, ANETTA WIECZOREK ${ }^{3}$, DOROTA NALEPKA ${ }^{4}$ \\ ${ }^{1}$ Department of Botany and Nature Conservation \\ University of Szczecin \\ Felczaka 3c, 71-412 Szczecin, Poland \\ e-mail: popiela@univ.szczecin.pl \\ ${ }^{2}$ Department of Environmental Protection and Management \\ Western Pomeranian University of Technology \\ Słowackiego 17, 71-434 Szczecin, Poland \\ ${ }^{3}$ Department of Ecology \\ University of Szczecin \\ Wąska 13, 71-412 Szczecin, Poland \\ ${ }^{4}$ Department of Palaeobotany \\ W. Szafer Institute of Botany, Polish Academy of Sciences \\ Lubicz 46, 31-512 Kraków, Poland
}

(Received: February 16, 2010. Accepted: June 14, 2010)

\begin{abstract}
General distribution map of Elatine hexandra (Lapierre) DC. was made based on literature and web-based data confronted and possible reasons of the formation of taxon's distribution range and history are discussed.
\end{abstract}

KEY WORDS: vascular plants, Elatinella, map, chorology, Isoëto-Nanojuncetea, Europe.

\section{INTRODUCTION}

Elatine hexandra (Lapierre) DC. belongs to a small cosmopolitan family of herbaceous aquatic and semi-aquatic plants and terrestrial shrubs - Elatinaceae, containing only just two genera, i.e. Elatine L. (about 15-25 taxa occurring in areas of moderate temperatures in both hemispheres), and Bergia L. (about 25 species occurring mostly in tropical areas of the Old World, first of all in Africa and Australia) (Tucker 1986; Leach 1989). Both genera are poorly known in respect of their phytogeography and taxonomy. No monograph of the genus Bergia has been published yet, whereas the only worldwide monograph of Elatine was published in the second half of the 19th century (Dumortier 1872). Of about 35-40 species of the family, a few have their general distribution mapped (see Hultén 1971; Meusel et al. 1978; Hultén and Fries 1986; Lampe 1996; Popiela and Łysko 2010).

Subdivision of the genus Elatine into lower units was proposed by Niedenzu (1925, after Seubert 1845) who allocated - based on leaves arrangement on stem - the subgenus Potamopithys (Adanson) Seub. and the subgenus Elatine (Hydropiper Moesz.) Seub. The latter includes two sections: Elatinella Seub. (number of stamens is double in relation to petals), and Triandra Seub. (=Crypta (Nutt. Seub.), in which he number of stamens is equal to that of petals (Tucker 1986). Elatine hexandra is one of eight species of the section Elatinella, of which six are found in Europe (three of them also in North Africa) $-E$. hexandra, $E$. macropoda Guss., E. gussonei (Sommier) Brullo, E. brochonii Clavaud, E. hungarica Moesz., E. orthosperma Dueben, one in Eurasia (E. hydropiper L.), and one in North America (E. californica Gray).

Against other taxa of the section, Elatine hexandra clearly distinguishes itself in respect of morphology by triple flowers placed on short pedicles that have six stamens and almost straight, rather robust, $0.5 \mathrm{~mm}$ long, yellow-brown, shiny seeds - hence, identification of this species does not create larger difficulties. It is found in the western and the central part of Europe. Although its general distribution maps have been already published three times (Meusel et al. 1978; Hultén and Fries 1986; Lampe 1996), there are however new data having been constantly gathered and mapping methods with the use of satellite base maps allow more accurate presentation of its distribution range.

This paper aims at making a general distribution map of Elatine hexandra and discussing possible reasons of formation of the taxon's distribution range and history. 


\section{METHODS}

The maps presented in this paper were made basing on floristic and phytosociological literature, search queries at the Kew Herbarium and the Herbarium of Natural History Museum in London, as well as web-based sources (Table 1). During research work, two types of data about species distribution were used: analogue data in the form of publications with information about location or paper map and electronic ones made available in web-based collections.

Electronic data were exported to *.shp format when they had geographical coordinated and then, due to their variation, they were given coordinates in common cartographic system WGS84. When geographical data (longitude and latitude) were missing, they were converted into text format and then, in case of detailed information about location, the record was digitalised manually on a satellite base map prepared earlier. When accurate description was missing and location was given only in cartogram grid, a cartogram was made according to principles for a given atlas and then spatial queries connecting grid area with map were used.
Paper data, in the form of location description, were mapped manually using satellite base map. In case of paper maps, calibration and rectification to UTM grid was made earlier and digitalisation was performed. The vector layers prepared this way were converted to WGS 84 reference system.

All analyses and maps were made using PostGIS spatial database extension software and QGIS (Quantum GIS) application software operating in the LINUX environment.

\section{RESULTS AND DISCUSSION}

Elatine hexandra belongs to the Holarctic element, the Sub-Atlantic and Central European sub-element (according to the approach of Pawłowska 1972). The species is found in habitats being temporarily flooded with water in communities of the alliance Elatini-Eleocharition ovatae, most abundantly in the association Eleocharo-Caricetum bohemicae Klika 1935 (syn. Eleocharetum ovatae) with the north-western type of distribution in Europe. Most phyto-

TABLE 1. Literature and web sources from which data where used to present the distribution of Elatine hexandra

\begin{tabular}{ll}
\hline Area & Data \\
\hline Skandinavia & $\begin{array}{l}\text { Vestergaard and Hansen 1989; Hultén 1971; Edqvist and Karlsson 2007; Uotila 2009 (www.flora- } \\
\text { nordica.org). } \\
\text { GBIF - Biodiversity occurrence data provided by: Herbarium of Oskarshamn (OHN), Oslo (O), Na- } \\
\text { tural History Museum, University of Oslo, Vascular Plants, Field notes, Oslo (O), Natural History } \\
\text { Museum, University of Oslo, University Museums of Norway (MUSIT), GBIF-Sweden, Vascular } \\
\text { plant herbarium, Agder naturmuseum og botaniske hage, Vascular Plant Herbarium, Trondheim } \\
\text { (TRH), (Accessed through GBIF Data Portal, www.gbif.net, 2009-12-08). }\end{array}$ \\
\hline
\end{tabular}

The middle, southern and south-eastern Europe Fiori and Paleotti 1896-1898; Pospichal 1897; Hayek 1927; Săvulescu 1955; Slavik 1990; Żukowski Środkowa, Poludniowa i poludniowo-wschodnia 1975; Heyny and Slavik 1990; Seitter 1977; Pignatti 1982; Maurer 1996; Popiela 1998, 2001; Popie(Poland, Czech, Slovakia, Austria, Slovenia, Roma- la et al. 2010 [in print]; Polatschek 1999; Stefanowic 1999; Jogan 2001; Nejc 2001. nia, the Balkan Peninsula, Italy)

GBIF - Biodiversity occurrence data provided by: Herbarium Berolinense, Botanic Garden and Botanical Museum Berlin-Dahlem, Bundesamt fuer Naturschutz / Netzwerk Phytodiversitaet Deutschland, Bundesamt für Naturschutz / Netzwerk Phytodiversität Deutschland, NLBIF Herbarium GJO Steiermärkisches Landesmuseum Joanneum, Karl Franzens University of Graz, Insitute for Botany - Herbarium GZU (Accessed through GBIF Data Portal, www.gbif.net, 2009-12-08).

The western and southwesten Europe (the British Boreau 1849; Lefèvre 1866; Saint-Lager 1873; Legué 1891; Tourlet 1908; Coste 1937; Coutinho Islands, France, Belgium, the Netherlands, Ger- 1939; Abbayes et al. 1971; Sjörgren 1973; Eriksson et al. 1974; Mennema et al. 1980; Corillion many, Schwitzerland Spain, Portugal)

1981; Guinochet and Vilmorin 1982; Haeupler and Schönfelder 1989; Cirujano and Velayos 1993; Berten 1993; Netien 1993; Provost 1993; Wohlgemuth 1993; Benkert et al. 1996; Bugnon et al. 1998; Bolomier and Cattin 1999; Preston et al. 2002; Catalogue Raisonné des Plantes Vasculaires de la Gironde 2005; Diard 2005; Duhamel and Hendoux 2005; Antonetti et al. 2006; Muller 2006; Boudin et al. 2007; Jeanmonod and Gamisans 2007; Brinkkemper et al. 2008.

Système d'Informations sur la Biodicersité en Wallonie (Accessed through http://biodiversite.wallonie.be, 2009-12.15)

Anthos (2009). Information System of the plants of Spain. Real Jardín Botánico, CSIC - Fundación Biodiversidad (Accessed through Anthos Portal, www.anthos.es 2009-12-02).

GBIF - Biodiversity occurrence data provided by: EUNIS European Environment Agency Real Jardin Botanico (Madrid), Vascular Plant Herbarium (MA) GBIF-Spain, Aranzadi Zientzi Elkartea GBIF-Spain, Universidad de Extremadura, UNEX, GBIF-Spain, Botanical Society of the British Isles - Vascular Plants Database UK National Biodiversity Network, Take a Pride in Fife Environmental Information Centre - Records for Fife from TAPIF EIC, UK National Biodiversity Network, Environment and Heritage Service - EHS Species Datasets, UK National Biodiversity Network, Observations du Conservatoire botanique national du Bassin parisien. Conservatoire botanique national du Bassin parisien Limnodata, Countryside Council for Wales - Freshwater site visits (species and habitats), UK National Biodiversity Network Botanical Society of the British Isles - Vascular plant data for Scottish Vice-counties (VCs 80, 84, 103 and 104), UK National Biodiversity Network, National Vegetation Data bank, NLBIF Inventaire national du Patrimoine naturel (INPN), Service du Patrimoine naturel, Muséum national d'Histoire naturelle, Paris Wetland Inventory (NV), Fundación Biodiversidad, Real Jardín Botánico (CSIC): Anthos. Sistema de Información de las plantas de España GBIF-Spain (Accessed through GBIF Data Portal, www.gbif.net, 2009-12-08) 


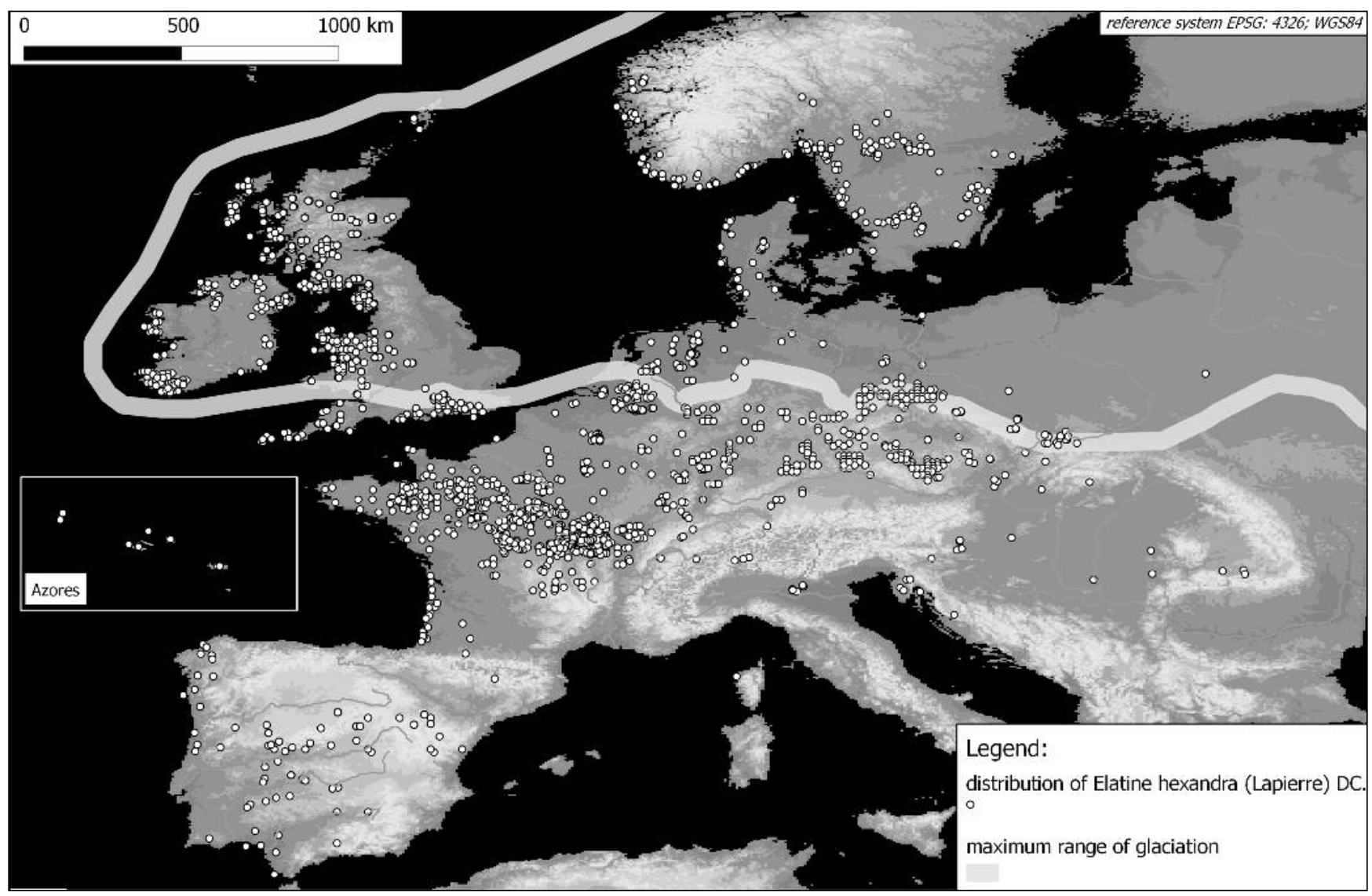

Fig. 1. Distribution of Elatine hexandra (Lapierre) DC. in Europe.

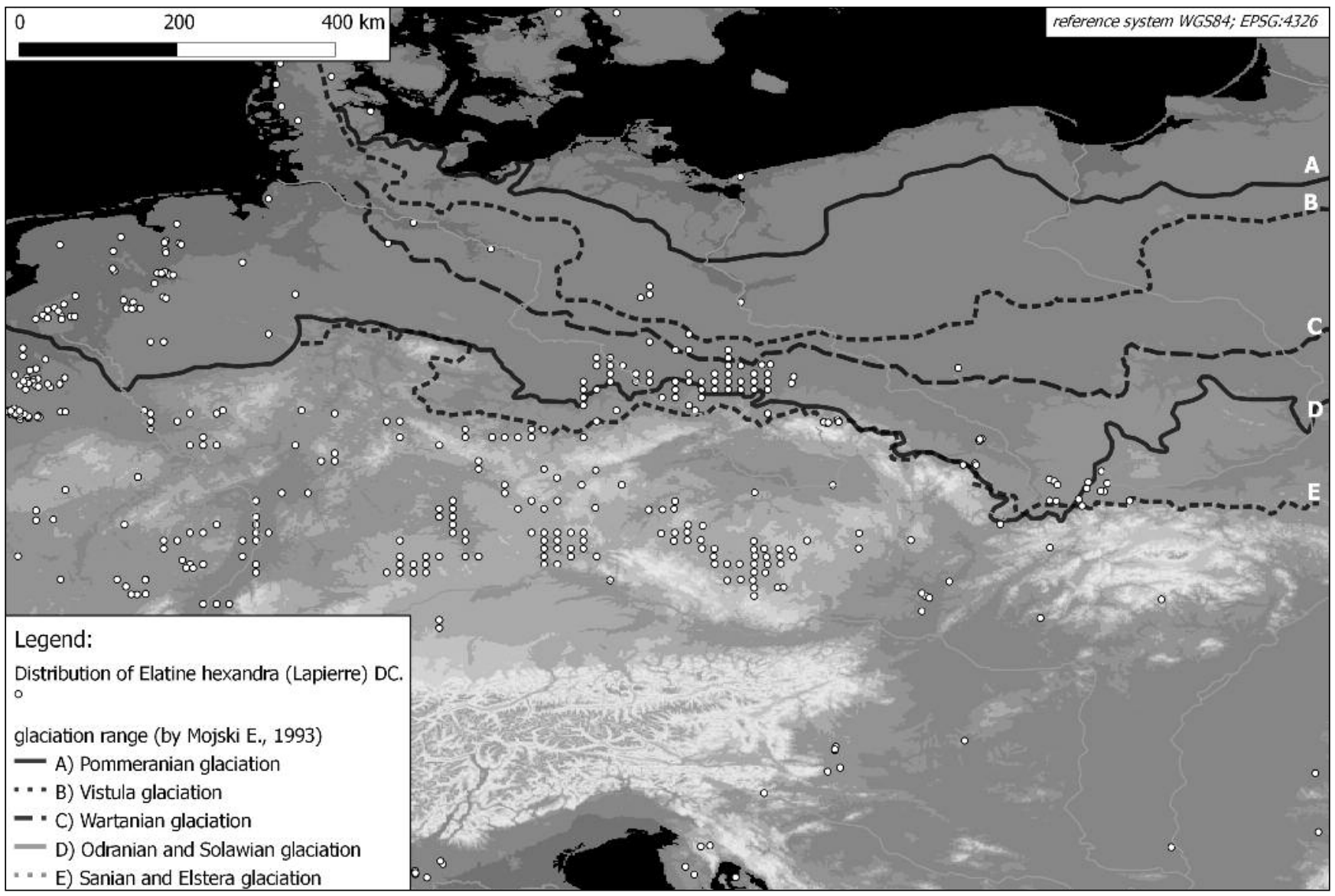

Fig. 2. Distribution of Elatine hexandra (Lapierre) DC. in Central Europe on the background of glacial coverage. 
sociological data come from Germany (Brullo and Minisalle 1998), while in Poland this association reaches the absolute north-eastern limits of its range (Popiela 2005; Popiela et al. 2010).

Locations of Elatine hexandra are being found in the Azores, British Isles (western and eastern Ireland, western and south-western Great Britain, Shetland Islands, and the Hebrides), and France (western Aquitaine, Brittany, Normandy, the western part of the Northern Plain, the Loire River Basin, and Burgundy); scattered locations in the Iberian Peninsula (mainly in the central part), the Netherlands (mainly in the Rhine, Meuse and Ems River Basins), in the southern part of the North German Plain and Plateau, in Lusatia, Moravia, Bohemia and Poland (Oświęcim Basin). Single floristic data are reported from the northern part of the Balkan Peninsula, Romania, Alpine valleys, the Po River Basin and Corsica. In Northern Europe, E. hexandra has isolated locations in the Jutland Peninsula, on western shores of the Scandinavian Peninsula and in Southern Sweden (Figs 1 and 2, Table 1). E. hexandra is not found outside Europe; its distribution range to the south of the continent borders on the home range of E. brochonii and E. macropoda, while to the east and north on that of E. triandra, E. hydropier and E. orthosperma.

From among eight species included in the section Elatinella Seub., Elatine hexandra is most probably the most closely related to E. brochonii - a taxon being known from single scattered locations in the Atlantic part of south-western France (Clavaud 1883; Fiton 1916; Schotsman and Bosserdet 1966; Vanden Berghen 1966; Olivier et al. 1995), in the central part of the Iberian Peninsula (Cirujano and Velayos 1993), in Morocco (Hamada et al. 2004; Fennane and Ibn Tattou 2005), in the Mediterranean part of Algeria (Quézel and Santa 1962-1963) and in Corsica (Lorenzoni and Paradis 1997). Both species are characterised by triple flowers and the presence of eight stamens but differ in the length of pedicel, seed size and structure as well as the position of flowers on stalk.

Distribution of Elatine hexandra as well as that of other species of the section and the genus suggests a long history of the range formation. Molecular phylogenetic studies, consisting in the comparison of sequences $\mathrm{rbcL}$, $\mathrm{ndhF}$ and PHYC, have maintained allocation of Elatinaceae (together with Clusiaceae) to the order Malphigiales (see Cronquist 1981), with the closest taxonomic relations being seen between Elatinaeae and Malpigiaceae (Davis and Chase 2004; Heywood et al. 2007). A common ancestor of both families could have occurred in the Cretaceous period at the beginning of Albian, i.e. 111-100 million years ago, while both families separated presumably at the end of this period, i.e. about 98-89 million years ago (Davis and Chase 2004; Davis et al. 2005). Based on fossil data and molecular findings, Davis et al. (2001) have raised a hypothesis that the family Malphigiaceae, and presumably also other families of the order Malpigiales, originates in the northern part of South America and then their representatives migrated to North America and later, via northern Atlantic, to the Old World.

Thus, the genus Elatine has undoubtedly a very long history going down to the Mediterranean Tertiary and the Madrean Tertiary floras in the northern hemisphere, while the hypothesis mentioned above referring to the migration route across Atlantic could explain disjunctive distribution patterns both within the order and the section Elatinella (seven species in Europe and one species in California).

Paleobotanical records of Elatine species elsewhere in Northwestern and Central Europe are very scarce, but they confirmed the presence of macro samples, seeds and pollen from, among others, the Pliocene, Middle Pleistocene and the Holocene (e.g. Latałowa 1992; Kvaček and Teodoridis 2007; Brinkkemper et al. 2008). A question about the Pleistocene refuge area of Elatine hexandra seems to be interesting. Two answers appear to be possible. When analysing its distribution map, attention is called by a concentration of the locations of this species to the north of the Alps - this may point to the existence of a hypothetic refuge in this region, in ice-free areas within the maximum range of glaciation (see Fig. 1). The second possibility is a refuge area in the Iberian Peninsula - a trace of it would be a single relic location existing there at present.

Many authors bring up a possibility of the formation of distribution range of ephemeral wetland flora, and the same of species of the genus Elatine, through general dispersal of diaspores by water and marsh birds (exozoochoria); this phenomenon is however very poorly examined, while no documentation is available for the genus Elatine at all (see Deil 2005 and references cited there as well as Brinkkemper et al. 2008). Therefore, while not excluding a possibility of the transport of diaspores by birds, it can be assumed that this does not occur frequently and the present pattern of distribution may have been invariable for very long time (seed bank in soil). A characteristic habitat for species of the genus Elatine are locations that are fluctuantly flooded. The original location of E. hexandra was presumably lakeand riversides, whereas at present many reported locations are from sites of the anthropogenic origin - most frequently from fish ponds with a controlled level of water table. Thus, its present distribution range has presumably an anthropogenic extension as far as the quantity of locations within it is concerned.

\section{ACKNOWLEDGEMENTS}

Funding was provided to A. Popiela by the Ministry of Science and Higher Education, Project No. PO4C03525. A. Popiela wishes to thank keepers of the Kew Herbarium and the Herbarium of Nature History Museum in London for providing access to herbarium materials.

\section{LITERATURE CITED}

ANTONETTI P., BRUGEL E., KESSLE F. 2006. Atlas de la flore d'Auvergne. Conservatoire botanique du Massif central, Chavaniac-Lafayette.

ABBAYES H., CLAUSTRES G., CORILLION R., DUPONT P. 1971. Flore Et vegetation du Massif Armoricain, Tome 1: La flore vasculaire. P.U.B. St Brieuc.

BENKERT D., FUKAREK F., KORSCH H. (eds). 1996. Verbreitungsatlas der Farn- Und Blütenpflanzen Ostdeutschlands. Gustav Fischer, Jena.

BERTEN B. 1993. Limburgse plantenatlas (pteridofyten en spermatofyten) 4. Limburgse plantenatlas, 4. Provincie Limburg: Hasselt.

BOLOMIER A.C., CATTIN P. 1999. La flore du département de l'Ain, inventaire complet. Connaissance de la flore de l'Ain. Bourg en Bresse. 
BOREAU A. 1849. Flore du Centre de la France. Ed. 1. Paris. Boudin L., Cordier J., Moret J. 2007. Atlas de la Flore Remarquable du Val de Loire Muséum National d'Histoire Naturelle, Paris.

BRINKKEMPER O., WEEDA E.J., SJOERD J.P. BOHNCKE S.J.P., KUIJPER W.J. 2008. The past and present occurrence of Elatine and implications for palaeoenvironmental reconstructions. Veget. Hist. Archaeobot. 17(1): 15-24.

BOUDIN L., CORDIER J., MORET J. 2007. Atlas de la Flore Remarquable du Val de Loire Muséum National d'Histoire Naturelle.

BUGNON F., FELZINES J.C., GOUX R., LOISEAU J.E. ROYER J.M. 1998. Nouvelle Flore de Bourgogne. Tome III. Atlas de repartition, clés des groupements vegetaux et supplements aux tomes I et II. Bull. Sci. de Bourgogne. Dijon.

BRULLO S., MINISSALE P. 1998. Considerazioni sintassonomiche sulla classe Isoëto- Nanojuncetea. Itinera Geobot. 11: 263-290.

Catalogue Raisonné des Plantes Vasculaires de la Gironde. 2005. Mém. Soc. Linn. Bordeaux, 4. Bordeaux.

CIRUJANO S., VELAYOS M. 1993. Elatine L. In: S. Castroviejo (ed.), Flora Iberica. 3. Real Jardín Botánico, Consejo Superior de Investigaciones Científicas.

CLAVAUD A. 1883. Communication. Actes Soc. Linn. Bordeaux 37: 52-55.

CORILLION R. 1981. Flore et végétation de la vallée de la Loire (cours occidental: de l'Orléanais l'estuaire). Jouve, Paris.

COSTE H. 1937. Flore descriptive et illustree de la France de la Corse et des contrées limitrophes. 1. Libraire scientifique et Technique, Paris.

COUTINHO A.X.P. 1939. Flora de Portugal: plantas vasculares. 2. Bertrand, Lisboa.

CRONQUIST A. 1988. The Evolution and Classification of Flowering Plants second edition. The New York Botanical Garden, New York.

DAVIS C.C., ANDERSON W.R., DONOGUE M.J. 2001. Phylogeny of Malpighiaceae: evidence from chloroplast ndhF and trnL-F nucleotide sequences. Am. J. Bot. 88: 1830-1846.

DAVIS C.C., CHASEM M.W. 2004. Elatinaceae are sister to Malpighiaceae; Peridiscaceae belong to Saxifragales. Am. J. Bot. 91: 262-273.

DAVIS C.C., WEBB C.O., WURDACK K.J., JARAMILLO C.A., DONOGHUE M.J. 2005. Explosive radiation of Malpighiales supports a mid-Cretaceous origin of modern tropical rain forests. Am. Nat. 165: E36-E65.

DEIL U. 2005. A review on habitats, plant traits and vegetation of ephemeral wetlands - a global perspective. Phytocoenologia 35(2-3): 533-705.

DIARD L. 2005. Atlas de La Flore d'Ille-et-Vilane. Siloë edition, Nantes.

DUHAMEL F., HENDOUX F. 2005. Plantes Protegees Menacees de la region Nord/Pas-de-Calais. Centre Regional de Phytosociologie Agree conservatoire Botanique Natinal de Bailleul.

DUMORTIER B.C. 1872. Examen critique des Élatinacées. Bull. Soc. Roy. Bot. Belg. 11: 254-274.

EDQVIST M., KARLSSON T. (ed.). 2007. Smålands flora. SBFförlaget, Uppsala.

ERIKSSON O., HANSEN A., SUNDING P. 1974. Flora of Macaronesia. Check-list of vascular plants. University of Umeå, Umeå.

FENNANE M., IBN TATTOU M. 2005. Flore vasculaire du Maroc, inventaire et chorologie. Vo1. Pteridophyta, Gymnospermae, Angiospermae. Travaux de 1'Institut Scientifique, Serie Bot. 37: 3-483.

FIORI A., PALEOTTI G. 1896. Flora analitica d'Italia. Padova.

FITON J. 1916. Elatine brochonii Clavaud. Soc. Franç. Echange Pl. Bull. 6: 28-30.

GUINOCHET M., VILMORIN R. de. 1982 Flore de France. Fasc. 4. Centre National de la Recherche Scientifique, Paris.
HAMMADA S., DAKKI M., IBN TATTOU M., OUYAHYA A., FENNANE M. 2004. Analyse de la biodiversité floristique des zones humides du Maroc. Flore rare, menacée et halophile. Acta Bot. Malacitana 29: 43-66.

HAYEK A. 1927. Prodomus Florae peninsulae Balcanicae. Band 1. Dahlem bei Berlin.

HAEUPLER H., SCHÖNFELDER P. 1989. Atlas der Farn- und Blütenpflanzen der BRD. 2. Stuttgart.

HEYNY S., SLAVIK B. (ed.). 1990. Kvetena Ceske Republiky 2. Praha. (in Czech)

HEYWOOD V.H., BRUMMITT R.K., CULHAM A., SEBERG O. 2007. Flowering Plant Families of the World. Royal Botanic Gardens, Kew.

HULTÉN E. 1971. The Circumpolar Plants. 2. Dicotyledones. Kungl. Svenska Vetenskapsakademiens Handingar, Fjarde Serien 13(1): 1-463.

HULTÉN E., FRIES M. 1986. Atlas of North European vascular plants, north of the tropic of Cancer. 1. Koelz Scientific Books, Königstein.

JEANMONOD D., GAMISANS J. 2007. Flora Corsica. Edisud, Aix-En Provence.

JOGAN N. (ed.). 2001. Gradivo za Atlas Flore Slovenije. Center za kartografijo favne in flore. Miklavž na Dravskem polju. (in Slovenian)

KVAČEK Z., TEODORIDIS V. 2007. Tertiary macrofloras of the Bohemian Massif: a Review with correlations within Boreal and Central Europe. Czech Geological Survey. Bull. Geosci. 82(4): 383-408.

LAMPE VON M. 1996. Wuchsform, Wuchsrhytmus und Verbreitung der Arten der Zwergbinsengesellschaften. Diss. Bot, 266: 1-351.

LATAŁOWA M. 1992. Man and vegetation in the pollen diagrams from Wolin Island (NW Poland). Acta Palaeobot. 32(1): 123-249.

LEACH G.J. 1989. Taxonomic revision of Bergia (Elatinaceae) in Australia. J. Adelaide Bot. Gard. 11: 75-100.

LEGUÉ L. 1891. Catalogue des Plantes Vasculares qui croissement naturellement dans le canton de Mondouleau. Paris-Auteuil.

LEFÈVRE E. 1866. Botanique du Départament d'Eure-et-Loir. Chartres, Petrot-Garnier.

LORENZONI C., PARADIS G. 1997. Description phytosociologique d'une mare temporaire à Elatine brochonii dans le sud de la Corse. Bull. Soc. Bot. Centre-Ouest N. S. 28: 21-46.

MAURER W. 1996. Flora der Steiermark. Band 1. Farnpflanzen (Pteridophyten) und freikoronblättige Blütenpflanzen (Apetale und Dialypetale). IHW Verlag. Eching.

MEUSEL H., JÄGER E., RAUSCHERT S., WEINERT E. 1978. Vergleichende Chorologie der Zentraleuropäischen Flora. 2. Karten. G. Fischer Verlag, Jena.

MENNEMA J., QUENÉ-BOTERENBROOD A.J., PLATE C.L. (eds). 1980. Atlas of the Netherlands Flora. 1. Extict and very rare species. Dr. W. Junk bv Publishers The Hague-BostonLondon.

MOJSKI J.E. 1993. Europa w plejstocenie ewolucja środowiska przyrodniczego. Polska Agencja Ekologiczna. Wydawnictwo PAE, Warszawa 1993. pp. 333. (in Polish)

MULLER S. 2006. Les Plantes Protegees De Lorraine - Distribution, Ecologie, Conservation. Biotope. Mèze.

NEJC J. (ed.). 2001. Materials for the Atlas of Flora of Slovenia. Center za kartografijo favne in flore. Miklavž na Dravskem polju. (in Slovenian)

NETIEN G. 1993. Flore lyonnaise. Société Linnéenne de Lyon, Lyon.

NIEDENZU F. 1925. Elatinaceae. In: A. Engler, K. Prantl, Die natürlichen Pflanzenfamilien, W. Engelmann, Leipzig.

OLIVIER L., GALLAND J.P., MAURIN H., ROUX J.P. 1995. Livre Rouge de la flore menacée de France. Tome I: espèces prioritaires. Museum National d'Histoire Naturelle, Service 
Patrimoine Naturel, Conservatoire Botanique National de Porquerolles, Ministère de l'Environnement, Paris.

PAWŁOWSKA S. 1972. Charakterystyka statystyczna i elementy flory polskiej. In: W. Szafer, K. Zarzycki (eds), Szata roślinna Polski. Państwowe Wydawnictwo Naukowe, Warszawa. (in Polish)

PETKOVIĆ B., MARTIN P., TATIĆ B. 1998. Genus Elatine L. in the Flora of Serbia. 2 Kongres na biolozite na Makedonja (so medjunarodno uèestvo), Zbornik na apstrakti, 24, Ohrid. (in Serbian)

PIGNATTI S. 1982. Flora D'Italia. 3. Edagricole, Bologna.

POLATSCHEK A. (ed.). 1999. Flora von Nordtilor, Osttilor und Vorarlberg. Tiroler Landesmuseum Ferdinandeum Innsbruck, Innsbruck.

POSPICHAL E. 1897. Flora des Oesterreichischen Küstenlandes. 1. Leipzig und Wien.

POPIELA A. 1998. Nowe stanowiska gatunków z rodzaju Elatine L. w Polsce. Bad. Fizjogr. Polską Zach. Ser. B-Botanika, 47: 257-264. (in Polish)

POPIELA A. 2001. Elatine hexandra (Lapierre) DC. In: A. Zając, M. Zajac (eds), Distribution Atlas of Vascular Plants in Poland. Nakładem Pracowni Chorologii Komputerowej Instytutu Botaniki Uniwersytetu Jagiellońskiego, Kraków.

POPIELA A. 2005. Isoëto-Nanojuncetea species and plant communities occurring on their eastern distribution range (Poland). Phytocoenologia: 35(2-3): 283-303.

POPIELA A., PRAJS B., ŁYSKO A. 2010. New data on distribution of dwarf ephemeral wetland vascular plant species/communities in the western and north-western Poland. Biodiversity: Res. Conserv. 14.

POPIELA A., ŁYSKO A. 2010. The distribution of Elatine macropoda Guss. (Elatinaceae). Acta Soc. Bot. Pol. 79(1): 81-86.

PRESTON C.D., PEARMAN D.A., DINES T.D. 2002. New Atlas of the British and Irish Flora. 912 pp. Published by Oxford University Press.

PROVOST M. 1993. Atlas de répartition des plantes vasculaires de Basse-Normandie. Univeristé de Caen. Caen.

QUEZEL P., SANTA S. 1962-1963. Nouvelle flore de l'Algérie et des régions désertiques méridionales. 2. Centre National Recherche Scientifique, Paris.
SAINT-LAGER J.-B. 1873. Catalogue des plantes vasculaires de la flore du bassin du Rhône / par le docteur Saint-Lager. Librairie H. Georg, Lyon.

SǍVULESCU T. (ed.). 1955. Flora Republicii Popularne Romine. Editura Academiei Republicii Populare Romine. Bukaresti. (in Romanian)

SCHOTSMAN H.D., BOSSERDET P. 1966. Notes sur Elatine brochonii Clav. Bull. Cent. Etud. Rech. Sc. Biarritz 6(2): 251-267.

SEITTER H. 1977. Die Flora des Fürstentums Liechtenstein. Botanisch-Zoologische Gesellschaft Liechtenstein-Sargans-Werdenberg, Vaduz.

SEUBERT M. 1845. Elatinarum monographia. Acad. Caes. Leop. Nova Acta 21: 34-60.

SJÖRGREN E. 1973. Recent changes in the vascular flora and vegetation of the Azores Island. Memorias da Societade Broteriana, 22: 5-453.

SLAVIK B. 1990. Fytokartografické syntézy ČSR. Phytogeographical syntheses of the ČSR. 2. Botanický ústav ČSAV. Botanical Institute of Czechoslovak Academy of Science Pruhonice. (in Czech)

STEFANOWIC V. (ed.). 1999. The red data book of flora of Serbia. 1. Extinct and critically endangered taxa. Ministry of environment of the Republic of Serbia. Belgrad. (in Serbian) TOURLET E.-H. 1908. Cataloque raisonné des Plantes vasculaires du departament d'Indre- et-Loire. Paris, Tours.

TUCKER G.C. 1986. The genera of Elatinaceae in the southeastern United States. J. Arnold Arbor. 67: 471-483.

UOTILA P. 2009. Elatine. In: Flora Nordica. 6. (www.floranordica.org, version 2006-11-23).

WOHLGEMUTH T., 1993. Der Verbreitungsatlas der Farn- und Blütenpflanzen der Schweiz (Welten und Sutter 1982) auf EDV. Die Artenzahlen und ihre Abhängigkeit von verschiedenen Faktoren. Bot. Helv. 103, 55-71.

VANDEN BERGHEN C. 1966. Deux localités nouvelles d' Elatine brochonii Clav. Bull. Cent. Etu. Rech. Sci. Biarritz 6(2): 269-270.

VESTERGAARD P., HANSEN K. 1989. Distribution of vascular plants in Denmark. Opera Bot. 96: 1-163.

ŻUKOWSKI W. 1975. Rodzaj Elatine L. w Polsce. Badan. Fizjogr. Pol. Zachod., B 28: 7-23. (in Polish) 